\title{
Does audit quality influence earnings management in emerging markets? Evidence from Jordan
}

\author{
Taha Suleiman Almarayeh ${ }^{\mathrm{a}}$, Beatriz Aibar-Guzmán ${ }^{b}$, Modar Abdullatif $^{\mathrm{c}}$ \\ a) Faculty of Business of Amman Arab University. Amman, Jordan. \\ b) Departamento de Economía Financiera y Contabilidad, Facultad de Ciencias Económicas y Empresariales, Universidad de Santiago de Compostela, Santiago de \\ Compostela, Spain. \\ c) Princess Sumaya University for Technology, King Talal School of Business Technology. Department of Accounting. Amman, Jordan.
}

\author{
${ }^{b}$ Corresponding author. \\ E-mail address: beatriz.aibar@usc.es
}

\section{A R T I C L E I N F O}

\section{Article history:}

Received 1 March 2019

Accepted 10 April 2019

Available online 1 January 2020

\section{JEL classification:}

M42

G30

Keywords:

Audit quality

Auditor size

Audit fees

Earnings management

Discretionary accruals

Jordan

\section{A B S T R A C T}

This study investigates whether some audit quality attributes are capable to restrict earnings management in a developing country, Jordan, whose cultural, economic and institutional context is very different from most previously analyzed countries context. Generalized least square regression (GLS) was used to study the association between two audit quality attributes (auditor size and audit fees) and discretionary accruals, as a proxy of earnings management, for a sample of industrial firms listed on the Amman Stock Exchange during the period 2012 2016. The findings are consistent with the expectation that in emerging countries external audit can function differently from that in Anglo-Saxon and West-European countries with regard to its role in restricting earnings management and indicate that, given the institutional environment in Jordan, auditor size and audit fees have no significant effect on earnings management. This study provides readers with information about if and how the institutional setting influences the relationship between audit quality and earnings management. Furthermore, it presents new evidence regarding the moderating effect of the level of audit fees on their relation with earnings management. This studys findings could provide valuable information to regulators and standards setters, both in Jordan and other countries with a similar economic and institutional environment, which can help in preventing earnings management practices.

(C)2020 ASEPUC. Published by EDITUM - Universidad de Murcia. This is an open access article under the CC BY-NC-ND license (http://creativecommons.org/licenses/by-nc-nd/4.0/).

¿Influye la calidad de la auditoría en la gestión de resultados en los mercados emergentes? Evidencia de Jordania

\section{R E S U M E N}

Este estudio investiga si algunos atributos de la calidad de auditoría son capaces de restringir la manipulación de resultados en un país en desarrollo, Jordania, cuyo contexto cultural, económico e institucional es muy diferente del contexto de los países analizados anteriormente. Se usó la regresión de mínimos cuadrados generalizada (GLS) para estudiar la asociación entre dos atributos de la calidad de auditoría (tamaño del auditor y honorarios de auditoría) y los ajustes por devengos discrecionales, como proxy de la manipulación de resultados, para una muestra de empresas industriales que cotizan en la Bolsa de valores de Amman durante el período 2012 - 2016. Los resultados son consistentes con la expectativa de que en los países emergentes la auditoría externa puede funcionar de manera diferente a la de los países anglosajones y de Europa occidental con respecto a su papel en la restricción de la manipulación de resultados e indican que, dado el entorno institucional en Jordania, el tamaño del auditor y los honorarios de auditoría no tienen un efecto significativo en la manipulación de resultados. Este estudio proporciona a los lectores información sobre si y cómo el entorno institucional influye en la relación entre la calidad de la auditoría y la manipulación de resultados. Además, presenta nueva evidencia sobre el efecto moderador del nivel de los honorarios de auditoría en su relación con la manipulación de resultados. Los resultados de este estudio podrían proporcionar información valiosa a los reguladores, tanto en Jordania como en otros países con un entorno económico e institucional similar, para prevenir las prácticas de manipulación de resultados.

(C)2020 ASEPUC. Publicado por EDITUM - Universidad de Murcia. Este es un artículo Open Access bajo la licencia CC BY-NC-ND (http://creativecommons.org/licenses/by-nc-nd/4.0/). 


\section{Introduction}

The recent corporate accounting scandals have sparked interest in the role of auditing in ensuring both the soundness of financial statements and the quality of reported earnings (Lin and Hwang, 2010) and have raised doubts about the quality of external auditing and its ability to restrict earnings management (Velury, 2003). As a result, many studies have analyzed the association between audit quality and earnings management. However, most of those studies are based on data from Anglo-Saxon countries and West-European countries and provide inconsistent evidence (Lin and Hwang, 2010). Previous studies have noted that differences in cultural, economic, institutional and legal factors among countries can affect both earnings quality (Leuz et al., 2003, Dechow et al., 2010; Enomoto et al., 2015) and the role of auditing in restraining earnings management (Maijoor and Vanstraelen, 2006; Choi and Wong, 2007; Lin and Hwang, 2010). Therefore, a plausible explanation of the prior research's mixed findings could lie in country-level factors.

In developing countries the level of investors' protection and the effectiveness of corporate governance mechanisms provided by firms to market participants are different from those in developed countries (Berkowitz et al., 2003; Iatridis, 2012; Bao and Lewellyn, 2017), which, in turn, encourages earnings management (Li et al., 2014). In this regard, Leuz et al. (2003) noted that earnings management is usually prevalent in those countries with less-developed stock markets, weak investor protection, concentrated ownership and weak legal enforcement. Similarly, the findings of Pacheco Paredes and Wheatley (2017) associated earnings management with cultures characterized by high power distance and higher levels of collectivism, typically characteristics of many emerging markets. Li et al. (2014) and Bao and Lewellyn (2017) also observed that earnings management activity tends to be higher in emerging countries compared to developed markets. Additionally, the efficacy of some audit quality attributes in constraining earnings management has been found more pronounced in certain countries than in others (Francis and Wang, 2008). Thus, this paper aims to shed light on the extent to which audit quality is capable to restrict earnings management in a developing country, Jordan, whose cultural, economic and institutional context is very different from most previously analyzed countries' context.

The Jordanian institutional setting is characterized by a code law tradition, weak investor protection and a small proportion of quoted firms (Francis and Wang, 2008; Abdullatif and Al-Khadash, 2010; Abdullatif, 2016). Additionally, ownership structure is concentrated and usually tied to members of the same family. In terms of audit quality, the Jordanian audit market offers an attractive setting to be studied for several reasons. First, in contrast to the Anglo-Saxon nations, the risk of litigation and punishments for abuser auditors is lower (Abdullatif and Al-Khadash, 2010). Second, financial bonding and personal relations between auditors and their clients are widespread and affect the auditor selection (World Bank, 2004; Abdullatif and Al-Khadash, 2010; Shbeilat and Abdel-Qader, 2018). Finally, the concentrated ownership structure of Jordanian firms causes a low demand for high-quality external audits and, consequently, audit fees are significantly lower compared with contexts characterized by dispersed ownership (Abdullatif and Al-Khadash, 2010; Niskanen et al., 2011). Previously, research has shown that earnings management behavior is widespread among Jordanian companies (Al-khabash and Al-Thuneibat, 2008; AlMousawi and Al-Thuneibat, 2011). Therefore, examining the association between audit quality and earnings management in the Jordanian context could provide valuable information about the role of external auditing in preventing earnings management in a cultural, economic, and institutional context very different from developed countries.

This study posits that in this context external auditing can function differently from that in Anglo-Saxon and WestEuropean countries with regard to its role in restricting earnings management. In order to investigate how external auditing can restrict earnings management practices, two proxies for audit quality were considered: audit firm size (Big Four vs non-Big Four) and audit fees. Data were gathered from the annual reports of a sample of Jordanian industrial firms listed on the Amman Stock Exchange (ASE) during the period 2012-2016. The regression results show that there is no influence for audit firm size in mitigating the level of earnings management, suggesting that there may be no differences in audit quality between Big Four and non-Big Four auditors in Jordan. In addition, the findings indicate that there is no association between audit fees and earnings management, suggesting that audit fees may not provide incentives for auditors to prevent or allow earnings management.

Empirical evidence on Jordan is limited. Al-Mousawi and Al-Thuneibat (2011) found that Big Four and non-Big Four audit firms are not significantly different in their ability to restrict earnings management practices. In a similar way, $\mathrm{Al}$ Thuneibat et al. (2011) observed that audit firm size does not affect the negative effect of longer audit firm tenure on audit quality and the magnitude of discretionary accruals. The data used in both of these studies was from 2002 to 2006, before the global financial crisis and the corporate governance code and related regulations mentioned earlier being enacted in Jordan. Based on data from 86 industrial firms listed on the ASE during the period 2007-2010, Alzoubi (2016) reported evidence that audit quality negatively affects earnings management. The data for this study come later such studies and after development of detailed corporate governance regulations in Jordan; so, to some extent, it attempts to explore whether the development of such regulations has achieved its intended aims of better corporate governance and shareholder protection in Jordan or not.

Thus, this paper aims to contribute to the existing literature on audit quality and earnings management in several ways. First, it provides data from a developing country with cultural, economic and social characteristics very different from those of most analyzed countries. Thus, this study's findings could enrich the understanding on the link between audit quality and earnings management across different institutional contexts and, specifically, to further learn if and how the institutional setting influences such a relationship. Hence, empirical evidence from this study can offer pertinent and valuable insights to the current debate regarding the effectiveness of external auditing in emerging markets. Second, this study's findings could provide valuable information to regulators and auditing standards setters, both in Jordan and other countries with a similar economic and institutional environment, in order to restrict earnings management. In the case of emerging markets, the reforms in financial reporting, auditing and corporate governance have been inspired by those introduced in developed countries, whose economic and institutional characteristics are different. In this sense, a better understanding of audit effectiveness in developing countries could help regulators to assess the impact of the planned reforms and to develop more effective legislation to enhance reported earnings' quality in emerging markets. 
The remaining of the paper proceeds as follows: the next section briefly outlines the development of the auditing profession in Jordan. Section 3 reviews the extant literature and develops the research hypotheses. Section 4 describes the research design, including the sample, data sources and the measurement of variables. Section 5 reports and discusses the empirical results. Section 6 includes robustness checks of the findings. Finally, the main conclusions of the study as well as its limitations and some ideas for future research are presented in Section 7.

\section{Development of the auditing profession in Jordan}

The auditing profession in Jordan has passed through several stages, each with relevant features, where the profession was influenced by the prevailing conditions and legislation at each stage. Historically, the beginnings of the auditing profession in Jordan can be dated back to 1944 (Abdullah, 1982), although until the beginning of 1960 s the practice of auditing was not regulated. In 1961 the Law of Practicing the Auditing Profession No. 10 was enacted and it introduced a licensing mechanism for entry to the auditing profession by establishing some general prerequisites for practicing auditing, but otherwise not much was mentioned regarding auditors' duties or rights (Abdullah, 1982). This law was revised in 1985 and the Law of Auditing Profession - Law No. 32 - was issued, which updated the conditions to be fulfilled to obtain an audit practice license as well as the rights and duties of external auditors. Furthermore, this law allowed auditors to joint into an association which contributed to developing the auditing profession (Solas, 1994). Under regulations related to this law, in 1987 the Jordanian Association of Certified Public Accountants (JACPA) was instituted.

The development of the audit profession in Jordan was fostered by the issuance of the Company Law No. 22 of 1997 and the Securities Law No. 76 of 2002. These laws rule the corporate financial reporting framework in Jordan and require the adoption of IFRS and ISAs (Al-Akra et al., 2009). The first one established the obligation to audit the annual reports and addressed matters such as the election of auditors, auditors' independence, remuneration, duties and liabilities. Furthermore, under regulations issued in 1998 in relation to the Companies Law of 1997, the International Financial Reporting Standards (IFRS) and the International Standards on Auditing (ISA) were formally adopted in Jordan for the first time. More recently, the Jordanian Corporate Governance Code (2008) and the last update for the regulations issued by the Jordan Securities Commission (JSC) in 2017 cover many issues relating to the conditions to be met by auditors in order to reinforce their independence. Specifically, the first one bans external auditors from providing additional services (i.e. technical consultation, administrative support or internal audit services) to their auditees.

The Jordanian audit market is mostly made up of small firms, although numerous international audit firms, including the Big Four, also practice in Jordan, using their own name or in association with a Jordanian audit firm (Abdullatif and Al-Khadash, 2010; Abdullatif, 2016). The practice of auditing is affected by two main characteristics of the Jordanian market. First, the vast majority of Jordanian firms are not publicly listed and, therefore, the Jordanian capital market is relatively small and inefficient with limited trade activity. Second, the Jordanian market is mainly comprised of family firms, and therefore there is reduced separation between management and ownership. These characteristics generate a low demand for the quality of external audit- ing which, in turn, causes a high competition among audit firms and lower audit fees. Furthermore, the risk of litigation against auditors is also low, contributing to higher possibilities of lower quality external auditing practice (Abdullatif and Al-Khadash, 2016). Furthermore, Jordan is somewhat a collectivist society (Al-Akra et al., 2009), where personal relations between clients and auditors are strong and play a significant role in the election of a company's auditor (World Bank, 2004; Abdullatif and Al-Khadash, 2010).

\section{Literature review and hypotheses development}

Prior literature has used different proxies to measure audit quality. This section provides a review of the literature that has examined the relationship between audit quality and earnings management, considering two input-based proxies for audit quality: audit size and audit fees.

\subsection{Auditor size and earnings management}

Audit firm size, usually defined by using a Big N vs. nonBig N dichotomy, is one of the most common proxies for audit quality in auditing literature (DeFond and Zhang, 2014). Research found that big audit firms can constrain earnings management in the USA (Becker et al., 1998; Francis et al., 1999; Chung et al., 2003; Lin and Hwang, 2010), where there are effective mechanisms to control auditors, but they may fail in preventing earnings management practices where the institutional setting does not promote high-quality audits (Jeong and Rho, 2004; Francis and Wang, 2008). Indeed, several non-US studies have found no difference between Big $\mathrm{N}$ and non-Big $\mathrm{N}$ firms in deterring earnings management (Vander Bauwhede et al., 2003; Jeong and Rho, 2004; Vander Bauwhede and Willekens, 2004; Piot and Janin, 2007). These findings have been explained based on several arguments. First, in those countries where the legal environment does not encourage high-quality audits because the risk of litigation is low or there are no effective disciplinary mechanisms to control opportunistic behaviors, Big $\mathrm{N}$ auditors and non-Big $\mathrm{N}$ auditors may provide comparable audit quality (Jeong and Rho, 2004; Maijoor and Vanstraelen, 2006; Francis and Wang, 2008). Second, since Big N and non-Big $\mathrm{N}$ firms are subjected to the same standards and legislation, both should provide a similar audit quality (Lawrence et al., 2011). Finally, in some cases small firms may even be more capable than their larger peers of detecting irregularities due to their greater knowledge of local markets (Louis, 2005).

In this respect, by using data from listed firms in three European countries (the UK, France, and Germany), Maijoor and Vanstraelen (2006) observed that Big N audit quality is not similar across different audit environment regimes. Specifically, they found that Big $\mathrm{N}$ audit firms were significantly superior to smaller audit firms in restricting earnings management in the UK, but not in France or Germany. In a similar way, Francis and Wang (2008) analyzed whether Big N audit firms behavior varies depending on the strictness of investor protection regimes. They analyzed a sample of firms from 42 countries and found that in weak investor protection regimes the quality of the firms' earnings was the same regardless of the size of their audit firm.

In developing countries investor protection is weaker than that in developed countries (Enomoto et al., 2015; Bao and Lewellyn, 2017). In such an institutional environment, auditors are less likely to exhibit a high level of independence (Jeong and Rho, 2004) and provide high-quality audits (Choi and Wong, 2007). Therefore, in such countries, there may be 
no differences in audit quality between Big $\mathrm{N}$ and non-Big $\mathrm{N}$ auditors (Francis and Wang, 2008). Furthermore, as indicated earlier, in Jordan, the litigation risk and penalties for auditors who abuse law are low (Abdullatif and Al-Khadash, 2010). Consequently, Big Four auditors arguably have limited motivation to exert effort in detecting problems and can be less strict on the misreporting of earnings by their clients.

As indicated earlier, the limited empirical evidence on the association between audit firm size and earnings management in Jordan is mixed. Al-Mousawi and Al-Thuneibat (2011) and Al-Thuneibat et al. (2011) found that Big Four and non-Big Four audit firms are not significantly different in their ability to restrict earnings management practices, whereas Alzoubi (2016) documented a negative significant association between auditor size and earnings management. However, considering the characteristics of the Jordanian business context, it is hypothesized that there are no differences in earnings quality of Jordanian firms audited by Big Four and non-Big Four audit firms and, thus, the following hypothesis is stated:

H1: Given the institutional environment in Jordan, the size of the audit firm (Big Four vs. non-Big Four) is not related to the level of earnings management.

\subsection{Audit fees and earnings management}

Two opposing arguments exist in the literature concerning the relationship between audit fees and earnings management. On one hand, high audit fees could threaten the independence of auditors and create an economic tie between an audit firm and its clients, creating motivations for auditors to allow earnings management (DeAngelo, 1981) (Beck et al., 1988) (Eshleman and Guo, 2014) (Magee and Tseng, 1990). On the other hand, high audit fees are related with higher audit effort and stronger scrutiny which lead to higher earnings quality (Srinidhi and Gul, 2007) (Gul et al., 2003; Lin and Hwang, 2010; Alali, 2011). Further, high audit fees are linked with audit firms' reputational capital, and, therefore, high audit fees provide a deterrent for auditors to allow earnings management (Frankel et al., 2002).

Empirical evidence on the relationship between audit fees and earnings management is mixed (Lin and Hwang, 2010). Several studies confirm the first argument regarding the existence of a positive relationship between audit fees and earnings management (Gul et al., 2003; Antle et al., 2006; Choi et al., 2010; Alali, 2011; Sharma et al., 2011; Gu and Hu, 2015; Donatella et al., 2018), whereas other studies support the second argument and document a negative association between them (Frankel et al., 2002; Srinidhi and Gul, 2007). Finally, some studies found that there is no association between audit fees and earnings management (Ashbaugh et al., 2003; Chung and Kallapur, 2003). Regarding developing countries, (Martinez and Moraes (2017)) document a negative association between audit fees and earnings management in the Brazilian market. These mixed findings can be caused by differences in economic conditions, audit markets and regulatory environments across countries (Maijoor and Vanstraelen, 2006). In this sense, Gu and Hu (2015) found that audit fees vary depending on the litigation environment, being higher in environments where litigation risk is higher. Junjian and Dan (2015) also observed that strong investor protection regimes have a moderating effect on the positive relationship between audit fees and earnings management.

The small Jordanian stock market offers a limited client base to audit firms. Furthermore, there are no grave con- sequences for companies switching auditors (Abdullatif and Al-Khadash 2010; Abdullatif 2016). In such a context, audit firms are subjected to competitive pressures to retain their clients, especially if their audit fees are relatively high, and they would therefore be willing to permit some discretion in reporting earnings by clients (Sharma et al., 2011). This situation, coupled with the low litigation risk in Jordan, leads to an expectation of positive association between audit fees and earnings management. Therefore, this study proposes the following hypothesis:

H2: Given the institutional environment in Jordan, audit fees are positively associated with the level of earnings management.

\section{Research methodology}

\subsection{Sample and data collection}

The sample for this study consists of all the industrial firms listed on the Amman Stock Exchange (ASE) during the period 2012-2016. The industrial sector was chosen because of its importance to the Jordanian economy, as it directly contributes to about a quarter of the national economy. Financial and insurance companies were excluded from the sample since they are subjected to dissimilar regulatory and procedural requirements. Furthermore, they apply distinctive accounting practices and, therefore, capturing opportunistic earnings manipulations is more difficult (Peasnell et al., 2000; Chen et al., 2005). Service companies were also excluded due to their different nature that could distort the results.

The initial sample included 395 firm-year observations from 2012 to 2016. However, 144 observations were excluded because they belonged to merged and liquidated firms or firms that did not have an available annual report. Thus, the final sample consists of 251 firm-year observations. The main source of data was the sample firms' annual reports published on the ASE's website corresponding to the period 2012-2016. This small sample size, similar than that of Alves (2013) and Alzoubi (2016), can be attributed to the characteristics of the Jordanian stock market. Data was obtained from the firms' annual reports available on the ASE's website, which were manually searched and analyzed by the researchers.

\subsection{Measurement of Variables}

\section{Dependent variable: Earnings management}

Several models can be used to measure earnings management. Most of them use discretionary accruals as a proxy for earnings management (Niu, 2006; Chang and Sun, 2009; Jaggi et al., 2009; Sun et al., 2010; Sun and Liu, 2011). Following prior research, this study employs the Kothari et al.'s (2005) performance adjusted model to estimate discretionary accruals due to its higher power of discovery of earnings management and fewer misspecification problems.

The discretionary accruals (DACKO) are calculated employing a cross-sectional variation of the performance adjusted model by Kothari et al. (2005), as it is more suitable for small samples.

As shown in equation (1), all variables, except the constant, are deflated by the total assets at the end of the previous year in order to adjust the differences in firm size and to reduce problems of heteroskedasticity. 
$\mathrm{TA}_{\mathrm{i}, \mathrm{t}} / \mathrm{A}_{\mathrm{i}, \mathrm{t}-1}=\alpha_{0, \mathrm{t}}+\alpha_{1, \mathrm{t}}\left(1 / \mathrm{A}_{\mathrm{i}, \mathrm{t}-1}\right)+\alpha 2, \mathrm{t}\left(\Delta(\mathrm{SALES}-\mathrm{REC})_{\mathrm{i}, \mathrm{t}}\right.$ $\left./ \mathrm{A}_{\mathrm{i}, \mathrm{t}-1}\right)+\alpha_{3, \mathrm{t}}\left(\mathrm{PPE}_{\mathrm{i}, \mathrm{t}} / \mathrm{A}_{\mathrm{i}, \mathrm{t}-1}\right)+\alpha_{4, \mathrm{t}}\left(\mathrm{ROA}_{\mathrm{i}, \mathrm{t}} / \mathrm{A}_{\mathrm{i}, \mathrm{t}-1}\right)+\varepsilon_{\mathrm{t}}(1)$ where $\mathrm{TA}_{\mathrm{i}, \mathrm{t}}$ are the total accruals for firm $\mathrm{i}$ in period $\mathrm{t} ; \mathrm{A}_{\mathrm{i}, \mathrm{t}} 1$ are the total assets for firm $i$ in period $t ; \Delta$ (SALES - REC $)_{i, t}$ represents the change in sales less accounts receivable for firm $i$ in period $t$; $P P E_{i, t}$ reflects the property, plant and equipment for firm $i$ in period $t$; and $\mathrm{ROA}_{\mathrm{i}, \mathrm{t}}$ is the return on assets for firm i in period $t$.

The non-discretionary accruals (NDACKO) are calculated by substituting the coefficients in equation (2) for the coefficients obtained from equation (1):

$\mathrm{NDACKO}_{\mathrm{i}, \mathrm{t}}=\mathrm{a}_{0, \mathrm{t}}+\mathrm{a}_{1, \mathrm{t}}\left(1 / \mathrm{A}_{\mathrm{i}, \mathrm{t}-1}\right)+\mathrm{a} 2, \mathrm{t}\left(\Delta(\text { SALES }-\mathrm{REC})_{\mathrm{i}, \mathrm{t}}\right.$ $\left./ \mathrm{A}_{\mathrm{i}, \mathrm{t}-1}\right)+\mathrm{a}_{3, \mathrm{t}}\left(\mathrm{PPE}_{\mathrm{i}, \mathrm{t}} / \mathrm{A}_{\mathrm{i}, \mathrm{t}-1}\right)+\mathrm{a}_{4, \mathrm{t}}\left(\mathrm{ROA}_{\mathrm{i}, \mathrm{t}} / \mathrm{A}_{\mathrm{i}, \mathrm{t}-1}\right)+\varepsilon_{\mathrm{t}}(2)$

Finally, the discretionary accruals (DACKO) are calculated by subtracting the non-discretionary accruals (equation 2) from the total accruals (equation 1), as shown in equation (3).

$\mathrm{DACKO}_{\text {it }}=\mathrm{TA}_{\text {it }}-\mathrm{NDACKO}_{\text {it }}$ (3)

Given that this research focuses on the magnitude rather than a particular direction of earnings management, the absolute value of discretionary accruals is utilized as the dependent variable (see Beck et al., 1988; Ianniello, 2015; Albersmann and Hohenfels, 2017).

\section{Independent variables: Audit quality proxies}

Audit firm size: Auditor Size (AUDSIZE) is defined as a dichotomous variable which receives the value of 1 if the financial statements of the firm $i$ in the period $t$ were audited by a Big Four audit firm and zero otherwise.

Audit fees: Consistent with former empirical studies (Gul et al., 2003; Alali, 2011; Lin et al., 2018), audit fees (AFEE) are defined as the natural logarithm of audit fees.

\section{Control variables}

In line with prior literature, several variables were included in the model, which reflect firm characteristics and earnings management incentives.

Firm size: firm size has often been used by earlier earnings management research as a control variable. Although Watts and Zimmerman (1990) and Jeong and Rho (2004) indicate that larger firms tend to manipulate earnings to report more predictable earnings, some other studies (Krishnan, 2003; Park and Shin, 2004; Piot and Janin, 2007; SánchezBallesta and García-Meca, 2007) document that large firms participate to a lower degree in earnings management. The mixed findings suggest no directional signs for the relationship between firm size and earnings management. Firm size (SIZE) is computed as the natural logarithm of total assets.

Firm leverage: many studies found that financially troubled firms tend to manage earnings downwards to take advantage of restructuring debt (DeAngelo et al., 1994; Becker et al., 1998; Jaggi and Lee, 2002; Jeong and Rho, 2004). However, another view is that highly leveraged firms will be under close scrutiny from their lenders, thus decreasing earnings management (Park and Shin, 2004). Due to such varying scenarios, the sign for the relation between firm leverage and earnings management is not predicted. Leverage (LEVERG) is measured as total long-term debt divided by total assets.

Firm growth: consistent with previous studies that documented a positive relation between the firm's growth rate and earnings management (Menon and Williams, 2004; Gul et al., 2009; Sáenz-González and García-Meca, 2014; Albersmann and Hohenfels, 2017), this study also predicts a positive sign in such a relationship. Firm growth (GROW) is measured as the market to book value ratio.

Firm performance: some authors argue that firms with lower performance have more motivation to manage earnings (Abdul Rahman and Ali, 2006). However, other studies (DeGeorge et al., 1999) found that firms performing highly tend to manage their earnings figures. Therefore, this study anticipates a relationship between firm performance and earnings management, but the sign of such a relationship is not predicted. Financial performance is measured by the Return on Assets (ROA) ratio, computed as net income divided by total assets.

Table 1 summarizes the definitions of the variables employed in this study.

Table 1

Summary of variable measurement

\begin{tabular}{|c|c|c|}
\hline Variable & Abbreviation & Definition \\
\hline $\begin{array}{l}\text { Earnings } \\
\text { management }\end{array}$ & DACKO & $\begin{array}{l}\text { The absolute value of the discretionary accruals } \\
\text { estimated following Kothari et al.'s (2005) model }\end{array}$ \\
\hline Auditor size & AUDSIZE & $\begin{array}{l}\text { Dummy variable which assumes the value of } 1 \text { if the } \\
\text { firm is audited by a Big Four auditor and } 0 \text { otherwise. }\end{array}$ \\
\hline Audit fees & AFEE & The natural logarithm of audit fees. \\
\hline Firm Size & SIZE & The natural logarithm of total assets. \\
\hline Firm Leverage & LEVERG & Total long-term debt divided by total assets. \\
\hline Growth & GROW & The market to book value ratio \\
\hline Performance & ROA & The net income divided by the total assets \\
\hline
\end{tabular}

\subsection{Model}

To test the proposed hypotheses, the following multiple regression model was estimated:

$\mathrm{DACKO}_{\mathrm{i}, \mathrm{t}}=\beta 0+\beta 1 \mathrm{AUDSIZE}_{\mathrm{i}, \mathrm{t}}+\beta 2 \mathrm{AFEE}_{\mathrm{i}, \mathrm{t}}+\beta 3$ LEVERG $_{\mathrm{i}, \mathrm{t}}+\beta 4$ SIZE $_{\mathrm{i}, \mathrm{t}}+\beta 5 \mathrm{GROW}_{\mathrm{i}, \mathrm{t}}+\beta 6 \mathrm{ROA}_{\mathrm{i}, \mathrm{t}}+\varepsilon_{\mathrm{i}, \mathrm{t}}$ (4)

Generalized least square regression (GLS) was used to study the association between audit quality attributes and earnings management. The present study contains both cross-sectional and time series data throughout the 251 firmyear observations of firms listed on the ASE during the period from 2012 to 2016.

\section{Results analysis and discussion}

\subsection{Descriptive Statistics}

Table 2 provides descriptive statistics of the variables employed in the regression analysis for the full sample of 251 firm-year observations over the period 2012-2016. The table is separated into three panels. The descriptive statistics for continuous and dichotomous variables for the full sample are summarized in panels A and B, respectively. Panel C displays the descriptive statistics categorized by audit firm size.

Panel A in Table 2 shows that the absolute values of discretionary accruals, estimated utilizing the Kothari et al. (2005) model (DACKO), have a mean (median) of 0.079 (0.054) and a standard deviation of 0.08 , indicating that the total volume of earnings management is $7.9 \%$ (5.4\%) of lagged total assets. These values are comparable with prior evidence from Jordan (Alzoubi, 2016) and other developing countries (Habbash and Alghamdi, 2017) as well as that from developed countries with weak investor protection regimes (Othman and Zeghal, 2006; Ianniello, 2015).

Regarding the independent variables, Panel B in Table 2 reports that Big Four auditors audit $26.7 \%$ of the sample companies, while companies audited by non-Big Four firms represent about $73.3 \%$ of the sample. Furthermore, panel $\mathrm{C}$ in 
Table 2 indicates that the proportion of audit fees paid to Big Four firms by their clients has a mean (median) of 4.3365 (4.0792) with a standard deviation of 0.4605 . However, the proportion of audit fees paid to the non-Big Four firms by their clients has a mean (median) of 3.8804 (3.8891) with a standard deviation of 0.2093 . This result is consistent with empirical evidence obtained by Choi et al (2008) that Big Four audit firms earn fees premium.

Regarding control variables, panel $\mathrm{C}$ in Table 2 displays that clients of Big Four audit firms are larger in size (mean = $7.51)$, leverage (mean $=41.21$ ) and growth (mean $=9.16$ ) but have a small ROA (mean $=-1.0552$ ) compared to clients of non-Big Four audit firms.

Table 2

Descriptive Statistics

\begin{tabular}{|c|c|c|c|c|c|c|c|c|c|c|}
\hline \multicolumn{11}{|c|}{ Panel A: Descriptive statistics of continuous variables (full sample $\mathrm{N}=251$ ) } \\
\hline Variable & \multicolumn{3}{|c|}{ Mean } & \multicolumn{2}{|l|}{ SD } & \multicolumn{2}{|l|}{ Min } & P50 & \multicolumn{2}{|r|}{ Max } \\
\hline DACKO & \multicolumn{3}{|c|}{0.07958} & \multicolumn{2}{|l|}{0.08296} & \multicolumn{2}{|l|}{0.00041} & 0.05447 & \multicolumn{2}{|c|}{0.52698} \\
\hline AFEE & \multicolumn{3}{|c|}{4.00251} & \multicolumn{2}{|l|}{0.35932} & \multicolumn{2}{|l|}{3} & 3.92942 & \multicolumn{2}{|r|}{5.27221} \\
\hline LEVERG & \multicolumn{3}{|c|}{33.6211} & \multicolumn{2}{|l|}{22.8215} & \multicolumn{2}{|l|}{0.39982} & 30.2928 & \multicolumn{2}{|c|}{115.468} \\
\hline SIZE & \multicolumn{3}{|c|}{7.23888} & \multicolumn{2}{|l|}{0.63189} & \multicolumn{2}{|l|}{5.46952} & 7.20824 & \multicolumn{2}{|r|}{9.08331} \\
\hline GROW & \multicolumn{3}{|c|}{3.4533} & \multicolumn{2}{|l|}{31.5135} & \multicolumn{2}{|l|}{-8.4} & 1.02143 & \multicolumn{2}{|r|}{500.134} \\
\hline ROA & \multicolumn{3}{|c|}{0.85876} & 10.6741 & & \multicolumn{2}{|l|}{-79.328} & 0.84775 & \multicolumn{2}{|r|}{40.3836} \\
\hline \multicolumn{11}{|c|}{ Panel B: Descriptive Statistics - Dichotomous Variables } \\
\hline Variable & Freque & ncy of 1's & (Yes) & Frequenc & cy of 0 's ( & & $\begin{array}{r}\text { ercentage } \\
\text { (Yes) }\end{array}$ & of 1's & $\begin{array}{r}\text { Percenta } \\
(\mathrm{N}\end{array}$ & $\begin{array}{l}\text { age of O's } \\
\text { No) }\end{array}$ \\
\hline AUDSIZE & & 67 & & & 184 & & $26.70 \%$ & & & $30 \%$ \\
\hline Panel C: De & escriptive & statistics & of contin & nuous var & riables by & audit firı & $\mathrm{m}$ size & & & \\
\hline Varioble & & Big F & Four $(\mathrm{N}=$ & $=69)$ & & & Non-Big & Four (N & $=186)$ & \\
\hline & Mean & SD & Min & P50 & Max & Mean & SD & Min & P50 & Max \\
\hline DACKO & 0.0791 & 0.0856 & 0.0007 & 0.0522 & 0.4495 & 0.0787 & 0.0811 & 0.0004 & 0.0543 & 0.527 \\
\hline AFEE & 4.3365 & 0.4605 & 3.699 & 4.0792 & 5.2722 & 3.8804 & 0.2093 & 3 & 3.8891 & 4.2553 \\
\hline LEVERG & 41.212 & 22.865 & 6.639 & 39.839 & 99.815 & 30.886 & 22.237 & 0.3998 & 27.286 & 115.46 \\
\hline SIZE & 7.5096 & 0.8645 & 5.4695 & 7.3661 & 9.0833 & 7.1414 & 0.4911 & 5.8608 & 7.1786 & 8.0799 \\
\hline GROW & 9.1597 & 60.918 & 0 & 1.1066 & 500.13 & 1.3978 & 3.5747 & -8.4 & 0.993 & 45.429 \\
\hline ROA & -1.055 & 15.073 & -79.33 & 1.0147 & 18.659 & 1.5482 & 8.5053 & -28.37 & 0.8039 & 40.383 \\
\hline
\end{tabular}

\subsection{Correlation matrix}

Table 3 shows the Pearson's correlation matrix for the variables analyzed in this study. It shows that, whilst there are numerous statistically significant correlations among the explanatory variables, none of them are highly correlated, so it can be stated that there is no multicollinearity issue with the results. Besides, variance inflation factors (VIF) are low (all values are under 0.8), confirming the above conclusion.

A review of correlation coefficients in Table 3 highlights several observations. First, the level of discretionary accruals (DACKO) is negatively correlated with audit fees but the correlations are not very strong, while it is positively correlated with auditor size. Second, in terms of the control variables, firm leverage (LEVERG) and firm growth (GROW) are positively associated with the level of discretionary accruals (DACKO), while firm size (SIZE) and firm performance (ROA) are not.

It is worth mentioning that one of the highest correlations found is between the auditor size (AUDSIZE) and audit fees (AFEE): 0.569 (at a level of significance of 0.01). This correlation is expected, as it suggests that larger auditor size implies charging higher audit fees. This result is in line with evidence reported by Choi et al. (2008). Another high correlation was found between audit fees (AFEE) and firm size (SIZE): 0.682 (at a level of significance of 0.01), indicating that large clients tend to pay high audit fees.
Table 3

Pearson's correlation matrix

\begin{tabular}{l|lllllll}
\hline \multicolumn{1}{c}{ DACKO } & AUDSIZE & AFEE & LEVERG & SIZE & GROW & ROA & VIF \\
\hline DACKO & 1 & & & & & & \\
AUDSIZE & 0.007 & 1 & & & & & 1.65 \\
AFEE & $-0.140^{* *}$ & $0.569^{* * *}$ & 1 & & & & 2.78 \\
LEVERG & 0.087 & $0.200^{* *}$ & 0.1 & 1 & & & 1.1 \\
SIZE & $-0.296^{* * * *}$ & $-0.254^{* * *}$ & $0.682^{* * * *}$ & $0.130^{* *}$ & 1 & & 2.27 \\
GROW & $0.235^{* * * *}$ & 0.109 & -0.006 & $0.183^{* * *}$ & -0.022 & 1 & 1.12 \\
ROA & -0.042 & -0.109 & 0.102 & -0.103 & $0.328^{* * * *}-0.267^{* * *}$ & 1 & 1.28 \\
\hline
\end{tabular}

* Significant at the 0.05 level (2-tailed). ** Significant at the 0.01 level (2-tailed). $* * *$ Significant at the 0.001 level (2-tailed).

\subsection{Regression Results}

Table 4 reports the findings of GLS regressions of audit quality attributes (auditor size and audit fees) and discretionary accruals as a proxy for earnings management. As the dataset is in panel frame, the Hausman test was run to decide which model is best fitted to the data (the fixed effects (OLS) versus random effects (GLS)). The value was not significant $(P=0.7162)$ and, therefore, the null hypothesis cannot be rejected. Hence, the random effects model is considered as the most appropriate for this study.

Model 1 documents the basic model, which has only control variables incorporated in the formula, while the independent variables, auditor size and audit fees, are separately included in models 2 and 3, respectively. In addition, model 4 combines all the explanatory variables namely: auditor size and audit fees and control variables.

Table 4 reveals that models 2 and 4 have similar findings for the auditor size variable (the coefficient $\beta 1$ is positive and not significant), which means that audit firms (Big Four and non-Big Four) are not successful in limiting earnings management in the Jordanian setting. Thus, Hypothesis 1 is accepted. This result is consistent with the existing evidence in countries such as Korea (Jeong and Rho, 2004), Belgium (Vander Bauwhede and Willekens, 2004) and Greece (Tsipouridou and Spathis, 2012), which reports that there is no difference between auditors, either Big $\mathrm{N}$ or non-Big $\mathrm{N}$, in reducing the level of earnings management.

A possible explanation for this outcome may be based on the argument of Jeong and Rho (2004), who propose that in countries, such as Jordan, where the legal environment does not encourage high-quality audits and the risk of litigation is low, auditors are not motivated to restrict earnings management behavior. Thus, this finding extends and reinforces Maijoor and Vanstraelen's (2006) findings that the Big $\mathrm{N}$ audit quality effect depends on the country's legal tradition and investor protection regime.

Another plausible reason of this result could be found in that Big Four audit quality is not unchanged across offices (Francis and Yu, 2009) and "local idiosyncrasies" affect auditors' work (Belal et al., 2017). In this sense, our result confirms some authors' view (e.g. Abdullatif and Al-Khadash, 2010; Abdullatif, 2016) that in developing countries, like Jordan, Big Four audit firms may not be capable to apply their audit procedures and approaches uniformly.

With reference to Hypothesis 2, Table 4 reports that models 3 and 4 have similar results for the audit fees variable (the coefficient $\beta 2$ is positive and not significant). This indicates that audit fees may not motivate restricting earnings management. Thus, Hypothesis 2 is rejected. This finding contradicts Sharma et al.'s (2011) results, which indicate that there is a positive relationship between a client's economic importance and earnings management in New Zealand. It also con- 
tradicts previous evidence from developing countries regarding a negative relationship between audit fees and earnings management (Martinez and Moraes, 2017).

This result can be explained considering that the level of audit fees in Jordan is comparatively much lower than that in developed countries and even that in other countries in the Middle East region (Abdullatif and Al-Khadash, 2010). Consequently, given the low level of audit fees in Jordan, coupled with the low litigation risk, it is likely that audit fees do not constitute a motivation to accomplish more audit effort to restrict earnings management and, therefore, audit fees do not affect earnings quality.

Taking the results of Hypotheses 1 and 2 together, it can be said that audit quality attributes (auditor size and audit fees) do not affect the level of earnings management by Jordanian firms. This result can be attributed to the characteristics of the Jordanian institutional and economic setting that does not encourage auditors to provide high-quality audits.

For the control variables, the findings in Table 4 reveal that, in all models, the coefficient of firm size (SIZE) has a negative sign and is highly significant, suggesting that the smaller firms tend to tolerate more earning manipulations. This finding is consistent with preceding literature (Albersmann and Hohenfels, 2017; Alzoubi, 2016; Chi et al., 2015; Francis and Wang, 2008). In the second place, the coefficient of firm growth (GROW) has, as anticipated, a positive sign and is significant, suggesting that larger levels of growth may encourage managers to use aggressive earnings management practices. This finding is in line with prior research (Carcello and Nagy, 2004; Alzoubi, 2016; Albersmann and Hohenfels, 2017; Sáenz-González and García-Meca, 2014). In the third place, in columns 3 and 4 the coefficient of firm performance (ROA) shows a significant positive sign, indicating that firms with high performance are more likely to manage their earnings figures. This result is consistent with earlier studies in developing countries (Sáenz-González and García-Meca, 2014). Finally, our findings do not show any significant influence of firm leverage (LEVERG) on earnings management.

The goodness-of-fit (R-square) is around 0.171 for all models, which is comparable with those in related research (e.g. Chi et al. (2015), who obtained an R-square of 18\%).

Table 4

GLS regression results

\begin{tabular}{cccccc}
\hline Variables & $\begin{array}{c}\text { Predicted } \\
\text { sign. }\end{array}$ & Column 1 & Column 2 & Column 3 & Column 4 \\
\hline AUDSIZE & No & & 0.0157 & & 0.00489 \\
& & & $(1.24)$ & & $(0.36)$ \\
AFEE & + & & & 0.0352 & 0.0313 \\
& & & & $(1.51)$ & $(1.24)$ \\
LEVERG & $?$ & 0.000335 & 0.00029 & 0.000339 & 0.000322 \\
& & $(1.02)$ & $(0.86)$ & $(1.05)$ & $(0.98)$ \\
SIZE & $?$ & $-0.0475^{* * *}$ & $-0.0506^{* * *}$ & $-0.0615^{* * *}$ & $0.0610^{* * *}$ \\
& & $(-3.99)$ & $(-4.14)$ & $(-3.53)$ & $(-3.50)$ \\
GROW & + & $0.000659^{* * * *}$ & $0.000655^{* * * *}$ & $0.000670^{* * *}$ & $0.000668^{* * *}$ \\
& & $(10.02)$ & $(9.94)$ & $(9.78)$ & $(9.71)$ \\
ROA & $?$ & 0.00121 & 0.00131 & $0.00137^{*}$ & $0.00138^{*}$ \\
& & $(1.88)$ & $(1.96)$ & $(1.99)$ & $(2.00)$ \\
CONSTANT & & $0.408^{* * *}$ & $0.429 * * *$ & $0.368^{* * *}$ & $0.380^{* * * *}$ \\
& & $(4.68)$ & $(4.84)$ & $(5.01)$ & $(4.83)$ \\
$\mathrm{R}^{2}$ & & 0.166 & 0.171 & 0.177 & 0.177 \\
Observations & & 251 & 251 & 251 & 251 \\
\hline
\end{tabular}

* Significant at the 0.05 level (2-tailed). ** Significant at the 0.01 level (2tailed). *** Significant at the 0.001 level (2-tailed). Note: $t$ statistics in parentheses

\section{Robustness checks}

This section provides several additional analyses to confirm the validity and robustness of the findings. Firstly, alternative models of earnings management are employed and then the sample is partitioned by signed discretionary accruals.

\subsection{Further earnings management models}

In order to validate the power and robustness of our findings, this research relies on other alternative metrics that have been widely used in prior literature for calculating earnings management, namely the Jones (1991) model and the Modified Jones model (Dechow et al., 1995).

Table 5 documents the results of the GLS regression models, where the dependent variable is the discretionary accruals calculated by the Jones (1991) model (DACJ) and the Modified Jones model (DACMJ) (Dechow et al., 1995). Hence, it can be noted that both models present comparable conclusions to those obtained with the Kothari et al. (2005) model in Table 4. In particular, Table 5 reveals that the coefficients of auditor size (AUDSIZE) and audit fees (AFEE) are found to be negative and positive, respectively, and statistically insignificant at all significance levels in both models. These findings are similar than those showed in Table 4. In addition, the results of control variables also remain similar to those presented in Table 4. The goodness-of-fit (R-square) is around 0.20 for both models.

Table 5

GLS regression results using additional discretionary accruals models

\begin{tabular}{ccc}
\hline \multirow{2}{*}{ Variables } & Column 1 & Column 2 \\
& Jones Modified (1995) & Jones Original (1991) \\
\hline \multirow{2}{*}{ AUDSIZE } & -0.004 & -0.0102 \\
& $(-0.29)$ & $(-0.68)$ \\
AFEE & 0.0503 & 0.0541 \\
& $(1.67)$ & $(1.8)$ \\
LEVERG & 0.00046 & 0.000399 \\
& $(1.15)$ & $(1.03)$ \\
SIZE & $-0.0798^{* * *}$ & $-0.0792^{* * *}$ \\
& $(-3.51)$ & $(-3.51)$ \\
GROW & $0.000841^{* * *}$ & $0.000855^{* * *}$ \\
& $(8.86)$ & $(9.10)$ \\
ROA & $0.00272^{*}$ & $0.00278^{*}$ \\
& $(2.29)$ & $(2.38)$ \\
CONSTANT & $0.440^{* * *}$ & $0.424^{* * *}$ \\
& $(4.29)$ & $(3.99)$ \\
\hline $\mathrm{R}^{2}$ & 0.204 & 0.199 \\
Observations & 251 & 251 \\
\hline
\end{tabular}

* Significant at the 0.05 level (2-tailed). ** Significant at the 0.01 level (2-tailed). *** Significant at the 0.001 level (2-tailed). Note: $t$ statistics in parentheses

\subsection{Signed Accruals}

Following prior research (Gul et al., 2009; Alali, 2011; Tsipouridou and Spathis, 2012; Albersmann and Hohenfels, 2017; Habbash and Alghamdi, 2017), besides employing the absolute (unsigned) value of discretionary accruals, we also analyzed the signed earnings management with the aim of discovering possible different discretions practiced by managers to engage in earnings management (Ashbaugh et al., 2003; Jenkins et al., 2006). Therefore, the observations of 
the discretionary accruals were split into two groups: positive (income-increasing) discretionary accruals and negative (income-decreasing) discretionary accruals.

In terms of independent variables, the findings for auditor size (AUDSIZE) as well as for audit fees (AFEE) presented in Table 6 do not differ between both sub-samples (upwards or downwards earnings management) and remain unchanged (statistically insignificant) compared to our main results (Table 4).

With reference to the control variables, the coefficient of size (SIZE) is negative and statistically significant in the positive discretionary accruals sub-sample and positive and statistically significant in the negative discretionary accruals subsample, implying that the larger firms are more likely to manage earnings downwards. In addition, firms with higher growth (GROW) are more averse to manage earnings downwards. Finally, Table 6 demonstrates that leverage (LEVERG) has no impact on either direction on earnings management compared to the documented outcomes in the main analysis.

Table 6

GLS regression results - signed accruals

\begin{tabular}{|c|c|c|c|c|c|c|}
\hline \multirow{2}{*}{ Variables } & \multicolumn{3}{|c|}{$\begin{array}{l}\text { Positive earnings management } \\
\text { (increasing) DAC }+\end{array}$} & \multicolumn{3}{|c|}{$\begin{array}{c}\text { Negative earnings management (decreasing) } \\
\text { DAC- }\end{array}$} \\
\hline & $\begin{array}{l}\text { Column } 1 \\
\text { DACKO }\end{array}$ & $\begin{array}{c}\text { Column } 2 \\
\text { DACMJ }\end{array}$ & $\begin{array}{c}\text { Column } 3 \\
\text { DACJ }\end{array}$ & $\begin{array}{l}\text { Column } 1 \\
\text { DACKO }\end{array}$ & $\begin{array}{c}\text { Column } 2 \\
\text { DACMJ }\end{array}$ & $\begin{array}{c}\text { Column } 3 \\
\text { DACJ }\end{array}$ \\
\hline AUDSIZE & $\begin{array}{l}-0.00243 \\
(-0.14)\end{array}$ & $\begin{array}{c}-0.00859 \\
(-0.49)\end{array}$ & $\begin{array}{c}-0.00952 \\
(-0.54)\end{array}$ & $\begin{array}{l}-0.00873 \\
(-0.643)\end{array}$ & $\begin{array}{l}-0.0175 \\
(-0.94)\end{array}$ & $\begin{array}{c}-0.00702 \\
(-0.34)\end{array}$ \\
\hline AFEE & $\begin{array}{l}0.0103 \\
(0.36)\end{array}$ & $\begin{array}{c}0.00792 \\
(0.24)\end{array}$ & $\begin{array}{c}0.00962 \\
(0.29)\end{array}$ & $\begin{array}{l}-0.0311 \\
(-0.402)\end{array}$ & $\begin{array}{c}-0.00633 \\
(-0.16)\end{array}$ & $\begin{array}{c}-0.00768 \\
(-0.18)\end{array}$ \\
\hline LEVERG & $\begin{array}{c}0.000376 \\
(1.4)\end{array}$ & $\begin{array}{c}0.000803 \\
(1.86)\end{array}$ & $\begin{array}{c}0.000701 \\
(1.61)\end{array}$ & $\begin{array}{c}-0.000204 \\
(-0.703)\end{array}$ & $\begin{array}{l}-0.00146 \\
(-0.25)\end{array}$ & $\begin{array}{c}-0.0000264 \\
(-0.04)\end{array}$ \\
\hline SIZE & $\begin{array}{c}-0.0350^{*} \\
(-2.47)\end{array}$ & $\begin{array}{c}-0.0589 * * \\
(-2.80)\end{array}$ & $\begin{array}{c}-0.0636^{* *} \\
(-3.02)\end{array}$ & $\begin{array}{c}0.0797^{* * *} \\
(0.006)\end{array}$ & $\begin{array}{l}0.055 \\
(1.77)\end{array}$ & $\begin{array}{l}0.052 \\
(1.52)\end{array}$ \\
\hline GROW & $\begin{array}{l}0.0104 \\
(1.62)\end{array}$ & $\begin{array}{c}0.00581 \\
(0.85)\end{array}$ & $\begin{array}{c}0.00679 \\
(0.84)\end{array}$ & $\begin{array}{c}-0.000669^{* * *} \\
(-5.90)\end{array}$ & $\begin{array}{c}-0.000667^{* * *} \\
(-6.03)\end{array}$ & $\begin{array}{c}-0.000675^{* * *} \\
(-5.72)\end{array}$ \\
\hline ROA & $\begin{array}{c}0.00145 \\
(1.08)\end{array}$ & $\begin{array}{c}0.00698^{* * *} \\
(3.38)\end{array}$ & $\begin{array}{c}0.00660 * * * \\
(3.38)\end{array}$ & $\begin{array}{l}-0.00128 \\
(-0.311)\end{array}$ & $\begin{array}{c}-0.000268 \\
(-0.23)\end{array}$ & $\begin{array}{c}-0.0000851 \\
(-0.07)\end{array}$ \\
\hline CONSTANT & $\begin{array}{c}0.257^{* *} \\
(3.06)\end{array}$ & $\begin{array}{c}0.422^{* * *} \\
(3.31)\end{array}$ & $\begin{array}{c}0.455^{* * *} \\
(3.64)\end{array}$ & $\begin{array}{c}-0.524^{* * *} \\
(-3.98)\end{array}$ & $\begin{array}{l}-0.44 * * \\
(-3.07)\end{array}$ & $\begin{array}{l}-0.420^{*} \\
(-2.47)\end{array}$ \\
\hline $\mathrm{R}^{2}$ & 0.332 & 0.39 & 0.376 & 0.243 & 0.212 & 0.201 \\
\hline Observations & 134 & 128 & 130 & 117 & 123 & 121 \\
\hline
\end{tabular}

Significant at the 0.05 level (2-tailed). ** Significant at the 0.01 level (2-tailed). *** Significant at the 0.001 level (2-tailed). Note: T-statistics in parentheses

\section{Conclusions}

Previous literature has shown that the role of auditing in restricting earnings management practices is influenced by both firm-level and country-level factors (Maijoor and Vanstraelen, 2006; Choi and Wong, 2007; Francis and Wang, 2008; Lin and Hwang, 2010). As Bao and Lewellyn (2017) noted, in emerging markets both types of factors are dissimilar from those in developed countries. This study aimed to shed new light on the extent to which external auditing is capable to restrict earnings management in a developing country, Jordan, whose cultural, economic, and institutional context is very different from most previously analyzed countries' contexts (i.e. the Anglo-Saxon and West-European countries). To achieve this objective, this study investigated whether some audit quality attributes (i.e. auditor size and audit fees) have an impact on discretionary accruals, as a proxy of earnings management, for a sample of industrial firms listed on the ASE during the period $2012-2016$.

The findings indicate that auditor size and audit fees have no significant effect on earnings management. These findings support the authors' expectation that external auditing in Jordan can function differently from the Western moredeveloped contexts. This is arguably because of some aspects that Jordan shares with other emerging markets, such as concentrated ownership structure, lower investor protection, a small and relatively inefficient stock market, strong personal relations between auditors and their clients, a low demand for high-quality external audits, and a low appreciation of the value of auditing.

However, certain particular features of the Jordanian institutional context can also have influenced on these findings, namely cultural factors affecting the perception of auditor independence and the way in which auditors understand their work. Furthermore, given the low level of audit fees in Jordan, which are comparatively much lower than those in developed countries and even those in other countries in the Middle East region, this study finds that audit fees do not affect earnings quality. Consequently, audit fees have no influence on auditors' behavior in relation to earnings management, since their magnitude is low. Therefore, the findings of this study present new evidence regarding the effect of the level of audit fees on earnings management.

This study's findings support the view that in emerging markets, like Jordan, auditing may not be an efficient internal monitoring mechanism and, therefore, it can be said that the prediction made by the agency theory about the role of auditing in mitigating opportunistic earnings management activities is not always accurate. Thus, this study adds to the continuing discussion and controversy that surrounds the role of external auditing in restricting earnings management in different institutional, economic, and cultural contexts.

These findings can provide useful information to regulators and auditing standards-setters, both in Jordan and other countries with a similar institutional setting, as they imply that recent regulatory reforms in Jordan have not been effective in improving audit quality and strengthen auditor's independence in order to limit earnings management practices, and the audit profession still suffers severe flaws. Therefore, the findings have two important policy implications. On the hand, the fact that auditors perform differently depending on the strictness of the countries' investor protection regime should be considered when international audit standards, heavily influenced by the US institutional context, are introduced in emerging markets, because otherwise these standards could be ineffective. On the other hand, in the case of Jordan, the low audit fees and the lack of demand for highquality audits should be taken into account in considering any new reform aimed at strengthening the role of external auditing in restricting earnings management.

Finally, the knowledge of the relation between audit quality and earnings management in Jordan is still relatively low. This study extends and updates the limited empirical evidence on this issue in the Jordan context. Moreover, as the authors are aware, this study is the first one to explore the role of audit quality on restricting earnings management in the period after activation of the Jordanian Corporate Governance Code of 2008 (previous studies, such as AlMousawi and Al-Thuneibat, 2011, Al-Thuneibat et al., 2011, and Alzoubi, 2016, were all based on older data). Thus, to some extent, this study provides a test of the effect of such a code on earnings management, and finds that significant work is still to be done.

A number of limitations ought to be considered when explaining the findings. First, the paucity of information and inconsistent reporting formats over Jordanian firms block some input-based proxies for audit quality, such as industryspecialist auditors or tenure. As a result, this study has only 
used two variables: audit size (Big Four versus non-Big Four) and audit fees. Therefore, the association between audit quality and earnings management in Jordan could be further addressed in future research if such data become more available. Second, our results rely on the accuracy of discretionary accruals as an appropriate proxy for earnings management. Third, the findings may be somewhat limited by data availability. Finally, this study considers earnings management as an opportunistic behavior which aims to mislead shareholders or any other stakeholders through misrepresentation or masking true economic performance. Thus, interpretations of the findings are limited to the opportunistic argument.

The aforementioned limitations do not undervalue the importance of the results and valuable insights of this study, but give a worthy platform for future investigation. Thus, a potential avenue for future research could be to use other audit quality proxies of audit firms, such as output-based proxies (i.e. restatements or audit opinions). Future researchers could also consider other corporate governance mechanisms such as board of directors and audit committees in restricting earnings management in Jordan. Finally, future research may also use other approaches to investigate this relationship, for instance, using qualitative research methods.

\section{Funding}

This research did not receive any specific grant from funding agencies in the public, commercial or not-for-profit sectors.

\section{Declaration of interest}

The authors declare no conflict of interest.

\section{References}

Abdullah, K. 1982. The audit profession in Jordan and Kuwait: A comparative analytical study. Dirasat Journal, 9(2), 131-151.

Abdullatif, M. (2016). Auditing Fair Value Estimates in Developing Countries: The Case of Jordan. Asian Journal of Business and Accounting, 9(2), 101-140.

Abdullatif, M., \& Al-Khadash, H.A. (2010). Putting audit approaches in context: The case of business risk audits in Jordan. International Journal of Auditing, 14(1), 1-24. https: //doi.org/10.1111/j.1099-1123.2009.00400.x

Abdul Rahman, R., \& Ali, F.H.M. (2006). Board, audit committee, culture and earnings management: Malaysian evidence. Managerial Auditing Journal, 21(7), 783-804. https: //doi.org/10.1108/02686900610680549

Al-Akra, M., Ali, M. J., \& Marashdeh, O. (2009). Development of accounting regulation in Jordan. The International Journal of Accounting, 44(2), 163-186. https://doi.org/10. 1016/j.intacc.2009.03.003

Al-khabash, A.A., \& Al-Thuneibat, A.A. (2008). Earnings management practices from the perspective of external and internal auditors: Evidence from Jordan. Managerial Auditing Journal, 24(1), 58-80. https://doi.org/10.1108/ 02686900910919901

Al-Mousawi, R.J., \& Al-Thuneibat, A. (2011). The effect of audit quality on the earnings management activities. Dirasat: Administrative Sciences, 38(2), 614-628.

Al-Thuneibat, A.A., Issa, R.T.I.A., \& Baker, R.A.A. (2011). Do audit tenure and firm size contribute to audit qual- ity?: Empirical evidence from Jordan. Managerial Auditing Journal, 26(4), 317-334. https://doi.org/10.1108/ 02686901111124648

Alali, F. (2011). Audit fees and discretionary accruals: compensation structure effect. Managerial Auditing Journal, 26(2), 90-113. https://doi.org/10.1108/ 02686901111094994

Albersmann, B.T., \& Hohenfels, D. (2017). Audit Committees and Earnings Management - Evidence from the German Two-Tier Board System. Schmalenbach Business Review 18(2), 147-178. https://doi.org/10.1007/ s41464-017-0028-9

Alves, S. 2013. The impact of audit committee existence and external audit on earnings management. Journal of Financial Reporting \& Accounting, 11(2), 143-165. http: //dx.doi.org/10.1108/JFRA-04-2012-0018

Alzoubi, E.S.S. (2016). Audit quality and earnings management: evidence from Jordan. Journal of Applied Accounting Research, 17(2), 170-189. https://doi.org/10.1108/ JAAR-09-2014-0089

Antle, R., Gordon, E. Narayanamoorthy, G., \& Zhou, L. (2006). The joint determination of audit fees, non-audit fees, and abnormal accruals. Review of Quantitative Finance and Accounting, 27(3), 235-266. https://doi.org/10.1007/ s11156-006-9430-y

Ashbaugh, H., LaFond, R., \& Mayhew, B.W. (2003). Do nonaudit services compromise auditor independence? Further evidence. The Accounting Review, 78(3), 611-639. https://www.jstor.org/stable/3203219

Bao, S.R., \& Lewellyn, K.B. (2017). Ownership structure and earnings management in emerging markets - An institutionalized agengy perspective. International Business Review, 26(5), 828-838. https://doi.org/10.1016/j.ibusrev. 2017.02.002

Beck, P.J., Frecka, T.J., \& Solomon, I. (1988). An empirical analysis of the relationship between MAS involvement and auditor tenure: Implications for auditor independence. Journal of Accounting Literature, 7(1), 65-84.

Becker, C.L., DeFond, M.L., Jiambalvo, J., \& Subramanyam, K. (1998). The effect of audit quality on earnings management. Contemporary Accounting Research, 15(1), 1-24. https://doi.org/10.1111/j.1911-3846.1998.tb00547.x

Belal, A., Spence, C., Carter, C., \& Zhu, J. (2017). The Big 4 in Bangladesh: caught between the global and the local. Accounting, Auditing \& Accountability Journal, 30(1), 145163. https://doi.org/10.1108/AAAJ-10-2014-1840

Berkowitz, D., Pistor, K., \& Richard, J.-F. (2003). Economic development, legality, and the transplant effect. European Economic Review, 47(1), 165-195. https://doi.org/10. 1016/S0014-2921(01)00196-9

Carcello, J.V., \& Nagy, A.L. (2004). Audit firm tenure and fraudulent financial reporting. Auditing: A Journal of Practice \& Theory, 23(2), 55-69. https://doi.org/10.2308/aud. 2004.23.2.55

Chang, J.C., \& Sun, H.-L. (2009). Crossed-listed foreign firms' earnings informativeness, earnings management and disclosures of corporate governance information under SOX. The International Journal of Accounting, 44(1), 1-32. https: //doi.org/10.1016/j.intacc.2008.12.004

Chen, K.Y., Lin, K.-L., \& Zhou, J. (2005). Audit quality and earnings management for Taiwan IPO firms. Managerial Auditing Journal, 20(1), 86-104. https://doi.org/10.1108/ 02686900510570722

Chi, C.W., Hung, K., Cheng, H.W., \& Lieu, P.T. (2015). Family firms and earnings management in Taiwan: Influence of corporate governance. International Review of Economics \& 
Finance, 36, 88-98. https://doi.org/10.1016/j.iref.2014.11. 009

Choi, J.-H., \& Wong, T.J. (2007). Auditors' governance functions and legal environments: an international investigation. Contemporary Accounting Research, 24(1),13-46. https://doi.org/10.1506/X478-1075-4PW5-1501

Choi, J.H., Kin, J.B., Liu, X., \& Simunic, D. (2008). Audit pricing, legal liability regimes, and Big 4 premiuns: theory and cross-country evidence. Contemporary Accounting Research, 25(1), 55-99. https://doi.org/10.1506/car.25.1.2

Choi, J.-H., Kim, J.-B, \& Zang, Y. (2010). Do abnormally high audit fees impair audit quality? Auditing: A Journal of Practice \& Theory, 29(2), 115-140. https://doi.org/10. 2308/aud.2010.29.2.115

Chung, H., \& Kallapur, S. (2003). Client importance, nonaudit services, and abnormal accruals. The Accounting Review, 78(4), 931-955. https://www.jstor.org/stable/ 3203285

Chung, R., Firth, M., \& Kim, J.B. (2003). Auditor conservatism and reported earnings. Accounting and Business Research, 33(1), 19-32. https://doi.org/10.1080/00014788. 2003.9729629

DeAngelo, L.E. (1981). Auditor size and audit quality. Journal of Accounting and Economics, 3(3), 183-199. https: //doi.org/10.1016/0165-4101(81)90002-1

DeAngelo, H., DeAngelo, L., \& Skinner, D.J. (1994). Accounting choice in troubled companies. Journal of Accounting and Economics, 17(1-2), 113-143. https://doi.org/10. 1016/0165-4101(94)90007-8.

Dechow, P.M., Sloan, R.G., \& Sweeney, A.P. (1995). Detecting earnings management. The Accounting Review, 70(2), 193-225. https://www.jstor.org/stable/248303

Dechow, P., Ge, W., \& Schrand, C. (2010). Understanding earnings quality: a review of the proxies, their determinants and their consequences. Journal of Accounting and Economics, 50(2-3), 344-401. https://doi.org/10.1016/j. jacceco.2010.09.001

DeFond, M., \& Zhang, J. (2014). A review of archival auditing research. Journal of Accounting and Economics, 58(2-3), 275-326. https://doi.org/10.1016/j.jacceco.2014.09.002

DeGeorge, F., Patel, J., \& Zeckhauser, R. (1999). Earnings management to exceed thresholds. The Journal of Business, 72(1), 1-33. https://www.jstor.org/stable/10.1086/209601

Donatella, P., Haraldsson, M., \& Tagesson, T. (2018). Do audit firm and audit costs/fees influence earnings management in Swedish municipalities? International Review of Administrative Sciences, Fothcoming. https://doi.org/10. 1177/0020852317748730

Enomoto, M., Kimura, F., \& Yamaguchi, T. (2015). Accrualbased and real earnings management: An international comparison for investor protection. Journal of Contemporary Accounting \& Economics, 11(3), 183-198. https://doi.org/10. 1016/j.jcae.2015.07.001

Eshleman, J.D., \& Guo, P. (2014). Abnormal audit fees and audit quality: The importance of considering managerial incentives in tests of earnings management. Auditing: A Journal of Practice \& Theory, 33(1), 117-138. https: //doi.org/10.2308/ajpt-50560

Francis, J.R., \& Wang, D. (2008). The joint effect of investor protection and Big 4 audits on earnings quality around the world. Contemporary Accounting Research, 25(1), 157191. https://doi.org/10.1506/car.25.1.6

Francis, J.R., \& Yu, M.D. (2009). Big 4 office size and audit quality. The Accounting Review, 84(5), 1521-1552. https: //www.jstor.org/stable/27784231

Francis, J.R., Maydew, E.L., \& Sparks, H.C. (1999). The role of big 6 auditors in the credible reporting of accruals. Auditing: A Journal of Practice \& Theory, 18(2), 17-34. https://doi.org/10.2308/aud.1999.18.2.17

Frankel, R.M., Johnson, M.F., \& Nelson, K.K. (2002). The relation between auditors' fees for nonaudit services and earnings management. The Accounting Review, 77(s-1), 71105. https://www.jstor.org/stable/3203326

Gu, J., \& Hu, D. (2015). Audit Fees, Earnings Management, and Litigation Risk: Evidence from Japanese Firms Cross-Listed on US Markets. Academy of Accounting and Financial Studies Journal, 19(3), 125

Gul, F.A., Chen, C.J., \& Tsui, J.S. (2003). Discretionary accounting accruals, managers' incentives, and audit fees. Contemporary Accounting Research, 20(3), 441-464. https: //doi.org/10.1506/686E-NF2J-73X6-G540

Gul, F.A., Fung, S.Y.K., \& Jaggi, B. (2009). Earnings quality: Some evidence on the role of auditor tenure and auditors' industry expertise. Journal of Accounting and Economics, 47(3), 265-287. https://doi.org/10.1016/j.jacceco.2009.03. 001

Habbash, M., \& Alghamdi, S. (2017). Audit quality and earnings management in less developed economies: the case of Saudi Arabia. Journal of Management \& Governance, 21(2), 351-373. https://doi.org/10.1007/ s10997-016-9347-3

Ianniello, G. (2015). The effects of board and auditor independence on earnings quality: evidence from Italy. Journal of Management \& Governance, 19(1), 229-253. https://doi. org/10.1007/s10997-013-9285-2

Iatridis, G.E. (2012). Audit quality in common-law and code-law emerging markets: evidence on earnings conservatism, agency costs and cost of equity. Emerging Markets Review, 13(2), 101-117. https://doi.org/10.1016/j.ememar. 2012.01.001

Jaggi, B., \& Lee, P. (2002). Earnings management response to debt covenant violations and debt restructuring. Journal of Accounting, Auditing \& Finance, 17(4), 295-324. https: //doi.org/10.1177/0148558X0201700402

Jaggi, B., Leung, S., \& Gul, F. (2009). Family control, board independence and earnings management: Evidence based on Hong Kong firms. Journal of Accounting and Public Policy, 28(4), 281-300. https://doi.org/10.1016/j. jaccpubpol.2009.06.002

Jenkins, D.S., Kane, G.D., \& Velury, U. (2006). Earnings quality decline and the effect of industry specialist auditors: An analysis of the late 1990s. Journal of Accounting and Public Policy, 25(1), 71-90. https://doi.org/10.1016/j. jaccpubpol.2005.11.003

Jeong, S.W., \& Rho, J. (2004). Big Six auditors and audit quality: The Korean evidence. The International Journal of Accounting, 39(2), 175-196. https://doi.org/10.1016/j. intacc.2004.02.001

Jones, J.J. (1991). Earnings management during import relief investigations. Journal of Accounting Research, 29(2), 193-228.

Junjian, G., \& Dan, H. (2015). Audit fees, earnings management and litigation risk: Evidence from Japanese firms cross-listed on U.S. markets. Academy of Accounting \& Financial Studies Journal, 19(3), 125-139

Kothari, S.P., Leone, A.J., \& Wasley, C.E. (2005). Performance matched discretionary accrual measures. Journal of Accounting and Economics, 39(1), 163-197. https://doi.org/ 10.1016/j.jacceco.2004.02.003

Krishnan, G.V. (2003). Does Big 6 auditor industry expertise constrain earnings management? Accounting Horizons, 
17(supplement), 1-16.

Lawrence, A., Minutti-Meza, M., Zhang, P. 2011. Can Big 4 versus non-Big 4 differences in audit-quality proxies be attributed to client characteristics?. The Accounting Review, 86(1),259-286. https://www.jstor.org/stable/29780232

Leuz, C., Nanda, D., \& Wysocki, P.D. (2003). Earnings management and investor protection: an international comparison. Journal of Financial Economics, 69(3), 505-527. https://doi.org/10.1016/S0304-405X(03)00121-1

Li, S., Park, S.H., \& Bao, R.S. (2014). How much can we trust the financial report? Earnings management in emerging economies. International Journal of Emerging Markets, 9(1), 33-53. , https://doi.org/10.1108/IJoEM-09-2013-0144

Lin, J.W., \& Hwang, M.I. (2010). Audit Quality, Corporate Governance, and Earnings Management: A Meta-Analysis. International Joural of Auditing, 14, 57-77. doi:10.1111/j. 1099-1123.2009.00403.x

Lin, F, Lin, Y., \& Chen, C. (2018). Accrual reversals and audit fees: the role of abnormal audit fees. Asia-Pacific Journal of Accounting \& Economics, 25(1-2), 276-294. https: //doi.org/10.1080/16081625.2016.1256784

Louis, H. (2005). Acquirers' abnormal returns and the nonBig 4 auditor clientele effect. Journal of Accounting and Economics, 40(1-3),75-99. https://doi.org/10.1016/j.jacceco. 2005.03.001

Magee, R. P., \& Tseng, M.-C. (1990). Audit pricing and independence. The Accounting Review, 65(2), 315-336. https: //www.jstor.org/stable/247627

Maijoor, S.J., \& Vanstraelen, A. (2006). Earnings management within Europe: the effects of member state audit environment, audit firm quality and international capital markets. Accounting and Business Research, 36(1), 33-52. https: //doi.org/10.1080/00014788.2006.9730005

Martinez, A.L., \& Moraes, A. (2017). Relationship between auditors' fees and earnings management. Revista de Administração de Empresas, 57(2), 148-157. http://dx. doi.org/10.1590/s0034-759020170204

Menon, K., \& Williams, D.D. (2004). Former audit partners and abnormal accruals. The Accounting Review, 79(4), 1095-1118. https://www.jstor.org/stable/4093087

Niskanen, M., Karjalainen, J., \& Niskanen, J. (2011). Demand for audit quality in private firms: evidence on ownership effects. International Journal of Auditing, 15(1), 43-65. https://doi.org/10.1111/j.1099-1123.2010.00422.x

Niu, F.F. (2006). Corporate governance and the quality of accounting earnings: a Canadian perspective. International Journal of Managerial Finance, 2(4), 302-327. https://doi. org/10.1108/17439130610705508

Othman, H.B., \& Zeghal, D. (2006). A study of earningsmanagement motives in the Anglo-American and EuroContinental accounting models: The Canadian and French cases. The International Journal of Accounting, 41(4), 406435. https://doi.org/10.1016/j.intacc.2006.09.004

Pacheco Paredes, A.A., \& Wheatley, C. (2017). The influence of culture on real earnings management. International Journal of Emerging Markets, 12(1), 38-57. https: //doi.org/10.1108/IJoEM-12-2014-0218

Park, Y.W., \& Shin, H.-H. (2004). Board composition and earnings management in Canada. Journal of Corporate Finance, 10(3), 431-457. https://doi.org/10.1016/ S0929-1199(03)00025-7

Peasnell, K.V., Pope, P.F., \& Young, S. (2000). Detecting earnings management using cross-sectional abnormal accruals models. Accounting and Business Research, 30(4), 313326. https://doi.org/10.1080/00014788.2000.9728949

Piot, C., \& Janin, R. (2007). External auditors, audit com- mittees and earnings management in France. European Accounting Review, 16(2), 429-454. https://doi.org/10.1080/ 09638180701391030

Sáenz-González, J.S., \& García-Meca, E. (2014). Does corporate governance influence earnings management in Latin American markets? Journal of Business Ethics, 121(3), 419440. https://doi.org/10.1007/s10551-013-1700-8

Sánchez-Ballesta, J.P., \& García-Meca, E. (2007). Ownership structure, discretionary accruals and the informativeness of earnings. Corporate Governance: An International Review, 15(4), 677-691. https://doi.org/10.1111/j. 1467-8683.2007.00596.x

Sharma V.D., Sharma, D. S., \& Ananthanarayanan U. (2011). Client Importance and Earnings Management: The Moderating Role of Audit Committees. Auditing: A Journal of Practice \& Theory, 30(3), 125-156. https://doi.org/10. 2308/ajpt-10111

Shbeilat, M., \& Abdel-Qader, W. (2018). Independence Dilemma and the Reliability of the Audit Report: Qualitative Evidence from Jordan. Australian Academy of Accounting \& Finanace Review, 4(1), 22-36

Solas, C. 1994. Financial reporting practice in Jordan: An empirical test. Advances in International Accounting, 7(1),43-60

Srinidhi, B., \& Gul, F.A. (2007). The differential effects of auditors' non-audit and audit fees on accrual quality. Contemporary Accounting Research, 24(2), 595-629. https:// doi.org/10.1506/ARJ4-20P3-201K-3752

Sun, J., \& Liu, G. (2011). Client-specific litigation risk and audit quality differentiation. Managerial Auditing Journal, 26(4), 300-316. https://doi.org/10.1108/ 02686901111124639

Sun, N., Salama, A., Hussainey, K., \& Habbash, M. (2010). Corporate environmental disclosure, corporate governance and earnings management. Managerial Auditing Journal, 25(7), 679-700. https://doi.org/10.1108/ 02686901011061351

Tsipouridou, M., \& Spathis, C. (2012). Earnings management and the role of auditors in an unusual IFRS context: The case of Greece. Journal of International Accounting, Auditing and Taxation, 21(1), 62-78. https://doi.org/ 10.1016/j.intaccaudtax.2012.01.005

Vander Bauwhede, H., \& Willekens, M. (2004). Evidence on (the lack of) audit-quality differentiation in the private client segment of the Belgian audit market. European Accounting Review, 13(3), 501-522. https://doi.org/10.1080/ 0963818042000237106

Vander Bauwhede, H., Willekens, M., \& Gaeremynck, A. (2003). Audit firm size, public ownership, and firms' discretionary accruals management. The International Journal of Accounting, 38(1), 1-22. https://doi.org/10.1016/ S0020-7063(03)00004-9

Velury, U. (2003). The association between auditor industry specialization and earnings management. Research in Accounting Regulation, 16, 171-184. https://doi.org/10. 1016/S1052-0457(02)16010-3

Watts, R.L., \& Zimmerman, J.L. (1990). Positive accounting theory: a ten year perspective. The Accounting Review, 65(1),131-156. http://www.jstor.org/stable/247880

World Bank (2004). Hashemite Kingdom of Jordan: Accounting and Auditing, World Bank: Washington DC. Retrieved from: https://openknowledge.worldbank.org/ handle/10986/14552 [accessed on November 14th, 2018] 